\title{
Transient changes of transforming growth factor- $\beta$ expression in the small intestine of the pig in association with weaning
}

\author{
Jie Mei and Ruo-Jun $\mathrm{Xu}^{*}$ \\ Department of Zoology, The University of Hong Kong, Pokfulam Road, Hong Kong \\ (Received 13 April 2004 - Revised 9 September 2004 - Accepted 11 September 2004)
}

\begin{abstract}
It is well known that early weaning causes marked changes in intestinal structure and function, and transforming growth factor- $\beta$ (TGF- $\beta$ ) is believed to play an important regulatory role in post-weaning adaptation of the small intestine. The present study examined the distribution and expression intensity of TGF$\beta$ in the small intestinal mucosa of pre- and post-weaning pigs using a specific immunostaining technique and Western blot analysis. The level of TGF- $\beta$ in the intestinal mucosa, as estimated by Western blot analysis, did not change significantly during weaning. However, when examined by the immunostaining technique, TGF- $\beta 1$ (one of the TGF- $\beta$ isoforms dominantly expressed in the tissue) at the intestinal villus epithelium, particularly at the apical membrane of the epithelium, decreased significantly $4 \mathrm{~d}$ after weaning, while the staining intensity increased significantly at the intestinal crypts compared with that in pre-weaning pigs. These changes were transient, with the immunostaining intensity for TGF- $\beta 1$ at the intestinal villi and the crypts returning to the preweaning level by $8 \mathrm{~d}$ post-weaning. The transient decrease in TGF- $\beta 1$ level at the intestinal villus epithelium was associated with obvious intestinal villus atrophy and marked reduction of mucosal digestive enzyme activities. Furthermore, the number of leucocytes staining positively for TGF- $\beta 1$ increased significantly in the pig intestinal lamina propria $4 \mathrm{~d}$ after weaning. These findings strongly suggest that TGF- $\beta$ plays an important role in the post-weaning adaptation process in the intestine of the pig.
\end{abstract}

Transforming growth factor- $\beta$ : Intestine: Weaning pig

It is well known that early weaning causes marked changes to the histology and biochemistry of the small intestine, such as villus atrophy and crypt hyperplasia, in both laboratory animals (Pluske et al. 1997) and human infants (Thompson et al. 1998). The change in intestinal structure often leads to reduced digestive and absorptive capacity and contributes to post-weaning diarrhoea. The aetiology of the intestinal structural alteration is complex, including enteropathogens, hypersensitivity to dietary antigens and withdrawal of milk-borne growth factors (Pluske et al. 1997; $\mathrm{Xu}$ et al. 2000). In most animals, the small intestine adapts to the weaning event and returns to normal functional capacity within 2 weeks after weaning (Hampson \& Kidder, 1986; Pluske et al. 1997). The mechanisms controlling the adaptation process are not yet clear, but transforming growth factor- $\beta$ (TGF- $\beta$ ) has been suspected to be an important modulator of postnatal intestinal adaptation (Xu et al. 2000).

TGF- $\beta$ is a multifunctional polypeptide expressed by various cells in the intestinal mucosa, including the epithelial cells lining the intestinal villi and the lymphocytes in the lamina propria (Barnard et al. 1993). It is synthesized initially as an inactive precursor of 390-412 amino acids and the mature active peptide consists of 112 amino acids (Yue \& Mulder, 2001). TGF- $\beta$ is secreted from cells in a latent complex consisting of TGF- $\beta$ in association with latent proteins and it needs to be activated to exert biological function (Roberts, 1995). TGF- $\beta$ regulates enterocyte proliferation and differentiation and helps to maintain intestinal integrity of the epithelial surface along the villi (Dignass \& Sturm, 2001). During injury or disease, TGF- $\beta$ stimulates epithelial cell migration (Ciacci et al. 1993) and extracellular matrix production (O'Kane \& Ferguson, 1997), thereby promoting wound healing. TGF- $\beta$ is also known as a potent immunoregulator and plays a critical role in maintaining mucosal immune homeostasis (Letterio \& Roberts, 1998), and local production of TGF- $\beta$ in the intestinal mucosa increases in response to mucosal inflammation (Babyatsky et al. 1996). These findings indicate that TGF- $\beta$ may be involved in relieving weaning-associated villus damage and mucosa inflammation. The aim of the present study was to examine the endogenous TGF- $\beta$ expression and its distribution in the small intestine of the pig during the weaning period.

\section{Materials and methods}

Tissue sample collection

Twelve Large White $\times$ Landrace pigs from two litters were used in the present study. The animals were allowed access to creep feed from $14 \mathrm{~d}$ of age. At $21 \mathrm{~d}$ of age, all animals were removed from the sows, four of the pigs designated pre-weaning pigs were killed for tissue sample collection within $2 \mathrm{~h}$ after removal and the remaining eight pigs were weaned to a soyabean- and maize-based weaning diet containing $22.2 \%$ crude protein. Four of the weaned pigs were killed for tissue sample collection $4 \mathrm{~d}$ 
after weaning and the remaining four weaned pigs were killed $8 \mathrm{~d}$ after weaning. Prior to tissue sample collection, all experimental animals were first anaesthetized by peritoneal injection of pentobarbital sodium (Alfasan, Wberden, Holland) and then euthanased by intracardiac injection of an overdose of the drug. Immediately after death, the small intestine was removed and placed in chilled saline. The small intestine was then freed from the mesentery and divided into the duodenum, jejunum and ileum as described previously (Xu et al. 1992).

A block of tissue (about $1 \mathrm{~cm}$ in length) was taken from the middle region of each intestinal segment for histological studies. Intestinal mucosa samples were collected from each segment of the small intestine by scraping with a glass slide. The tissue samples were immediately frozen in liquid $\mathrm{N}$ and then stored at $-70^{\circ} \mathrm{C}$ until used for further analyses of enzyme activities, protein and DNA contents and Western blot analysis.

\section{Immunohistochemical examination}

Tissue blocks collected for immunohistochemical study were immediately fixed in Bouin's fluid for $24 \mathrm{~h}$. The tissue blocks were then dehydrated through graded alcohol and embedded in paraffin wax. Cross-tissue sections of $5 \mu \mathrm{m}$ thickness were dewaxed in xylene, re-hydrated in alcohol solution of increased dilution, and then immersed in PBS. Endogenous peroxidase activity was eliminated by incubation with $1 \% \mathrm{H}_{2} \mathrm{O}_{2}$ for $30 \mathrm{~min}$, and non-specific binding was blocked by incubation for $30 \mathrm{~min}$ with $2 \%$ normal goat serum (DAKO A/S, Glostrup, Denmark). The tissue sections were then incubated overnight at $4^{\circ} \mathrm{C}$ with rabbit polyclonal antibodies specifically against TGF- $\beta 1, \beta 2$ or $\beta 3$. The antibodies were obtained from a commercial source (Santa Cruz Biotech, Santa Cruz, CA, USA) and were raised against a carboxy-terminus peptide of 15-26 amino acids of human TGF- $\beta 1, \beta 2$ or $\beta 3$. According to the information provided by the supplier, the antibodies detect both precursor and mature TGF- $\beta 1, \beta 2$ or $\beta 3$ from various species including the pig. After three washes in PBS, sections were further incubated for $2 \mathrm{~h}$ at room temperature with biotin-conjugated secondary antibodies, followed by three washes in PBS, and incubation for $2 \mathrm{~h}$ at room temperature with streptavidin-biotinylated horseradish peroxidase (Amersham Pharmacia Biotech, San Francisco, CA, USA). Subsequently, the slides were developed in 3,3-diaminobenzidine solution $(0.5 \mathrm{mg} / \mathrm{ml})$ in the presence of $0.1 \% \mathrm{H}_{2} \mathrm{O}_{2}$ for $10 \mathrm{~min}$. After washing in distilled water, the slides were counterstained with haematoxylin (Sigma, St Louis, MO, USA). The negative control sections were stained with the same procedures except that the primary antibodies were replaced with non-specific rabbit IgG (DAKO A/S). The tissue sections were then examined under light microscope (Carl Zeiss Inc., Werk Göttingen, Germany), and positive staining was visualized as dark brown spots.

The immunostaining intensity was semi-quantified following the procedures described by Ruifrok et al. (1997). The method has been validated in our laboratory recently (Mei et al. 2004). Briefly, TGF- $\beta$ immunoreactivity was quantified using a computerized image-analysis system (Quantimet 500; Leica Cambridge Ltd, Cambridge, UK). This system consisted of an IBM-compatible computer with image-analysis software, a Leica microscope (Leica Cambridge Ltd.), a colour video camera and a 'live image' monitor. The image was converted to an analogue electronic signal by the video camera and digitized by the computerized imaging board. The mean specific optical density (OD), reflecting the immunostaining intensity, was calculated from the formula: $\mathrm{OD}=\log _{10}[255 /(255$ - grayscalevalue $)]$, as described by Ruifrok et al. (1997). The integrated OD, which is the product of the area stained and the mean specific OD, was taken as a semi-quantitative measure of the total amount of TGF- $\beta$ protein present.

\section{Morphological analyses}

Paraffin tissue sections $(5 \mu \mathrm{m})$ were stained with haematoxylin and eosin. Following previous descriptions (Xu et al. 1992), morphological parameters, including the wall thickness, villus height, villus width and crypt depth, were analysed under a light microscope (Carl Zeiss Inc.) connected to an image processing and analysis system (Quantimet 500; Leica Cambridge Ltd).

Measurements of digestive enzyme activities and protein and DNA contents

Samples of small intestinal mucosa were homogenized with chilled saline using a polytron homogenizer (Kinematica AG, Littau/Lucerne, Switzerland). The activities of the sucrase (E.C. 3.2.1.48) and lactase (E.C. 3.2.1.23) in the small intestinal mucosa were determined by the method described by Dahlqvist (1964). Alkaline phosphatase (orthophosphoric monoester phosphohydrolase, EC 3.1.3.1) was determined by the method of Forstner et al. (1968). Protein concentration was determined with the Lowry method using bovine serum albumin as standard (Lowry et al. 1951). DNA was extracted from the tissue homogenates following the procedures described by Johnson \& Chandler (1973) and the DNA content was determined using the diphenylamine method (Giles \& Myers, 1964). Calf thymus DNA (Sigma) was used as standard.

\section{Western blot analysis}

Small intestine mucosa samples were defrosted and homogenized at $4^{\circ} \mathrm{C}$ in $50 \mathrm{~mm}$-Tris- $\mathrm{HCl}$ buffer, $\mathrm{pH} 6.8$, containing $5 \mathrm{~mm}-$ EDTA, $10 \mu \mathrm{g} / \mathrm{ml}$ phenylmethylsulphonyl fluoride and $0.2 \%$ NP-40, using a polytron homogenizer (Kinematica AG). Tissue debris was removed by centrifugation at $4500 \mathrm{rpm}$ for $30 \mathrm{~min}$. Protein concentrations of the tissue homogenates were measured with the Lowry method as described previously (Xu et al. 1992).

Molecular characteristics of immunoreactive TGF- $\beta$ peptides in the tissue homogenates were evaluated by SDS-PAGE and Western blot analysis as described by Rao et al. (2000). Briefly, tissue homogenates were diluted in $50 \mathrm{~mm}$-Tris $-\mathrm{HCl}$ buffer, $\mathrm{pH} 6 \cdot 8$, containing $2 \%$ SDS, $10 \%$ glycerol, $5 \%$ 2-mercaptoethanol and $0.05 \%$ bromophenol blue, and boiled for $5 \mathrm{~min}$. The prepared samples of equal amounts of protein $(50 \mu \mathrm{g})$ were then loaded onto $12 \%$ SDS-PAGE gel and separated in an electrophoresis unit (Mini-Protean II Cell; Bio-Rad, Hercules, CA, USA) at $120 \mathrm{~V}$ (constant voltage) for $1-2 \mathrm{~h}$. Separated proteins were then transferred onto nitrocellulose membranes (Amersham Pharmacia Biotech) at $100 \mathrm{~V} / 250 \mathrm{~mA}$ for $120 \mathrm{~min}$ at $4^{\circ} \mathrm{C}$. The nitrocellulose membranes were subsequently blocked with Tris-buffered saline $(100 \mathrm{mM}-$ Tris- $\mathrm{HCl}, \mathrm{pH} 7.5,0.9 \% \mathrm{NaCl}$ ) containing $0.1 \%$ Tween 20 and $5 \%$ skimmed milk powder for $2 \mathrm{~h}$ at room temperature followed by overnight incubation at $4{ }^{\circ} \mathrm{C}$ with polyclonal antibodies against TGF- $\beta 1,2$ or 3 , respectively (Santa Cruz Biotech). The membranes were then washed with Tris-buffered saline, followed by further $2 \mathrm{~h}$ incubation at room temperature with biotin-conjugated goat anti- 
rabbit IgG (Santa Cruz Biotech). After removing non-bound antibody, the membranes were then incubated for $2 \mathrm{~h}$ in a solution of streptavidin-biotinylated horseradish peroxidase complex. Subsequently, the membranes were developed in 3,3-diaminobenzidine solution $(0.2 \mathrm{mg} / \mathrm{ml})$ in the presence of $0.1 \% \mathrm{H}_{2} \mathrm{O}_{2}$ for $30 \mathrm{~min}$. The membranes were then air-dried and stored in light-protected boxes at room temperature until further examination. The molecular weights of the immunoreactive bands were determined using a molecular weight standard (Invitrogen, Carlsbad, CA, USA).

For quantitative analysis, the stained membranes were scanned and the intensity of the positive bands was measured using Bio-Rad's image-analysis system. The measured intensity of each sample was calibrated and converted to $\mathrm{mg}$ TGF- $\beta / \mathrm{g}$ protein and $\mathrm{mg}$ TGF- $\beta / \mathrm{mg}$ DNA by comparison with the intensity of known amounts of TGF- $\beta$ proteins (Santa Cruz Biotech).

\section{Statistics}

The results are expressed as mean and standard error of the mean. One-way ANOVA was used to compare variances among various groups. Statistical differences between two groups were assessed by the least significant difference test. All analyses were conducted using SPSS for Windows software, version 11.0 (SPSS Inc., Chicago, IL, USA). A difference with $P$ value $<0.05$ was considered significant.

\section{Results}

Changes of intestinal morphology and digestive enzyme activities in association with weaning

Weaning caused significant changes in the intestinal morphology and digestive enzyme activities, as shown in Figs. 1 and 2 and Tables 1 and 2. The changes were as expected and observations were consistent with reports in the literature.

\section{Changes of transforming growth factor- $\beta$ expression and distribution in the small intestine}

In pre-weaning pigs, immunostaining with specific antibodies for TGF- $\beta 1$ was seen on both apical and basal membranes of the villus epithelium in the duodenal region of the small intestine (Fig. 1). The same staining pattern was seen in the jejunal region of the small intestine (photo not shown). However, in the ileal region of the small intestine, immunostaining with TGF- $\beta 1$ specific antibodies was observed predominantly on the basal side of the villus epithelium (Fig. 1). There were numerous leucocytes that were positively stained with TGF- $\beta 1$ antibodies and scattered in the lamina propria of the small intestine (Fig. 2). The immunostaining patterns with antibodies specific for TGF- $\beta 2$ and TGF- $\beta 3$ at the villus epithelium were similar to those of staining with specific antibodies for TGF- $\beta 1$. The epithelial cells at the intestinal crypts along the small intestine were positively stained with antibodies against the three TGF- $\beta$ isoforms. No staining was observed in duodenal Brunner's glands.

Four days after weaning, the immunostaining for TGF- $\beta 1$ at the apical membrane of the villus epithelium became weaker in the duodenal and jejunal region of the small intestine compared with that in pre-weaning pigs (Fig. 1), while the staining for TGF- $\beta 1$ at the intestinal crypts became much stronger (Fig. 2). No obvious distribution change was noted in the ileal villus epithelium following weaning (Fig. 1). Similar to that in the duodenum and the jejunum, the epithelial cells at the ileal crypts stained strongly for TGF- $\beta 1$ in pigs 4 and $8 \mathrm{~d}$ after weaning. In the lamina propria of the small intestine, the number of leucocytes positively stained with TGF- $\beta 1$ antibodies increased significantly $4 \mathrm{~d}$ after weaning (Fig. 3).

Quantification of immunohistochemical staining by image analysis showed a transient decline in the positive staining area and integrated staining intensity (OD) for TGF- $\beta 1$ at the villus epithelium in the duodenal and jejunal region of the pig small intestine following weaning (Fig. 4), while the integrated OD
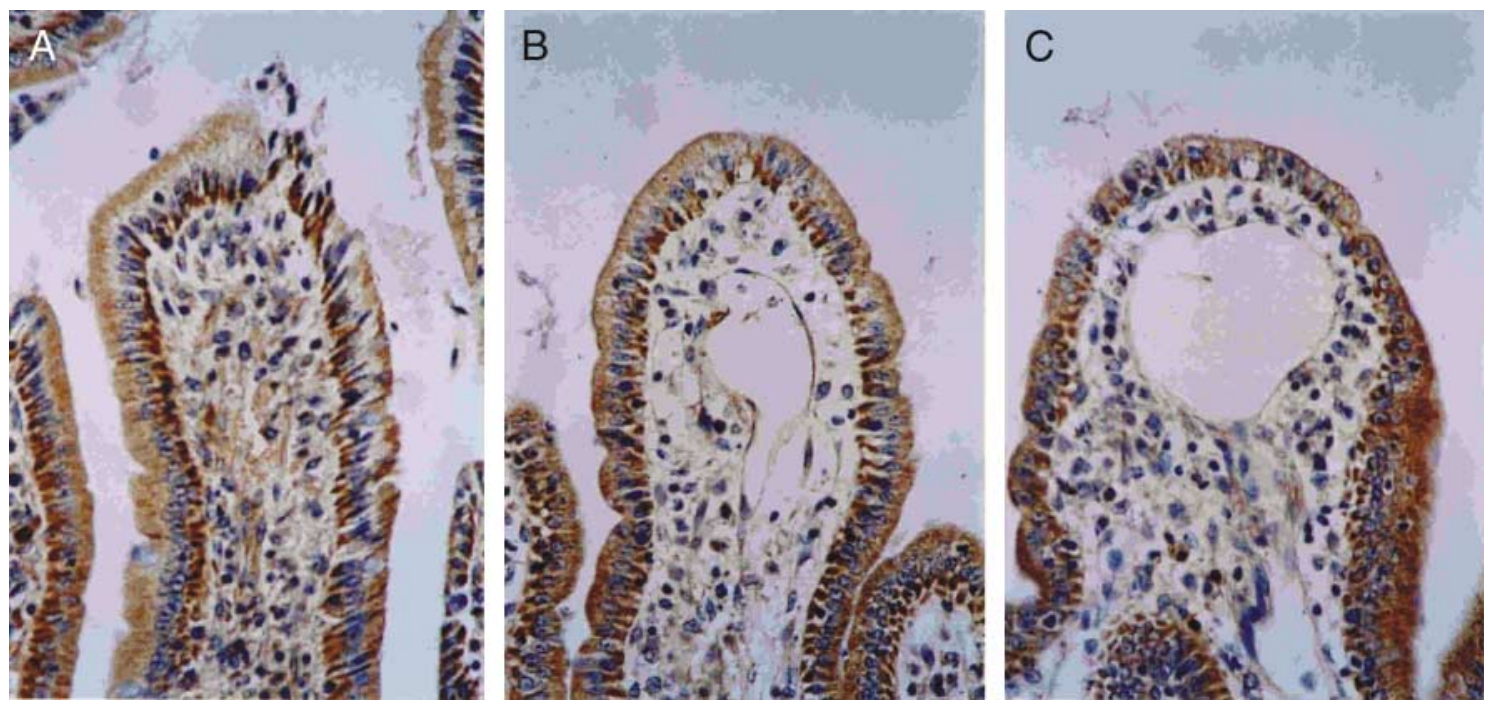

Fig. 1. Representative photomicrographs of duodenal (upper panels) and ileal (lower panels) villi from pre-weaning (A), $4 \mathrm{~d}$ post-weaning (B) and $8 \mathrm{~d}$ post-weaning (C) pigs (magnification $350 \times$ ). Tissue sections were incubated with polyclonal antibodies against transforming growth factor- $\beta 1$ (TGF- $\beta 1$ ), and colour was developed using the avidin-peroxidase system. In the duodenum, immunostaining of TGF- $\beta 1$ was seen on both apical and basal membrane of the villus epithelium in pre-weaning pigs. The immunostaining intensity at the apical membrane declined markedly in $4 \mathrm{~d}$ post-weaning pigs and then recovered to the pre-weaning value in $8 \mathrm{~d}$ post-weaning pigs. In the ileum, TGF- $\beta 1$ was located predominantly on the basal side of the villus epithelial membranes in pre-weaning pigs. The immunostaining declined gradually following weaning. 

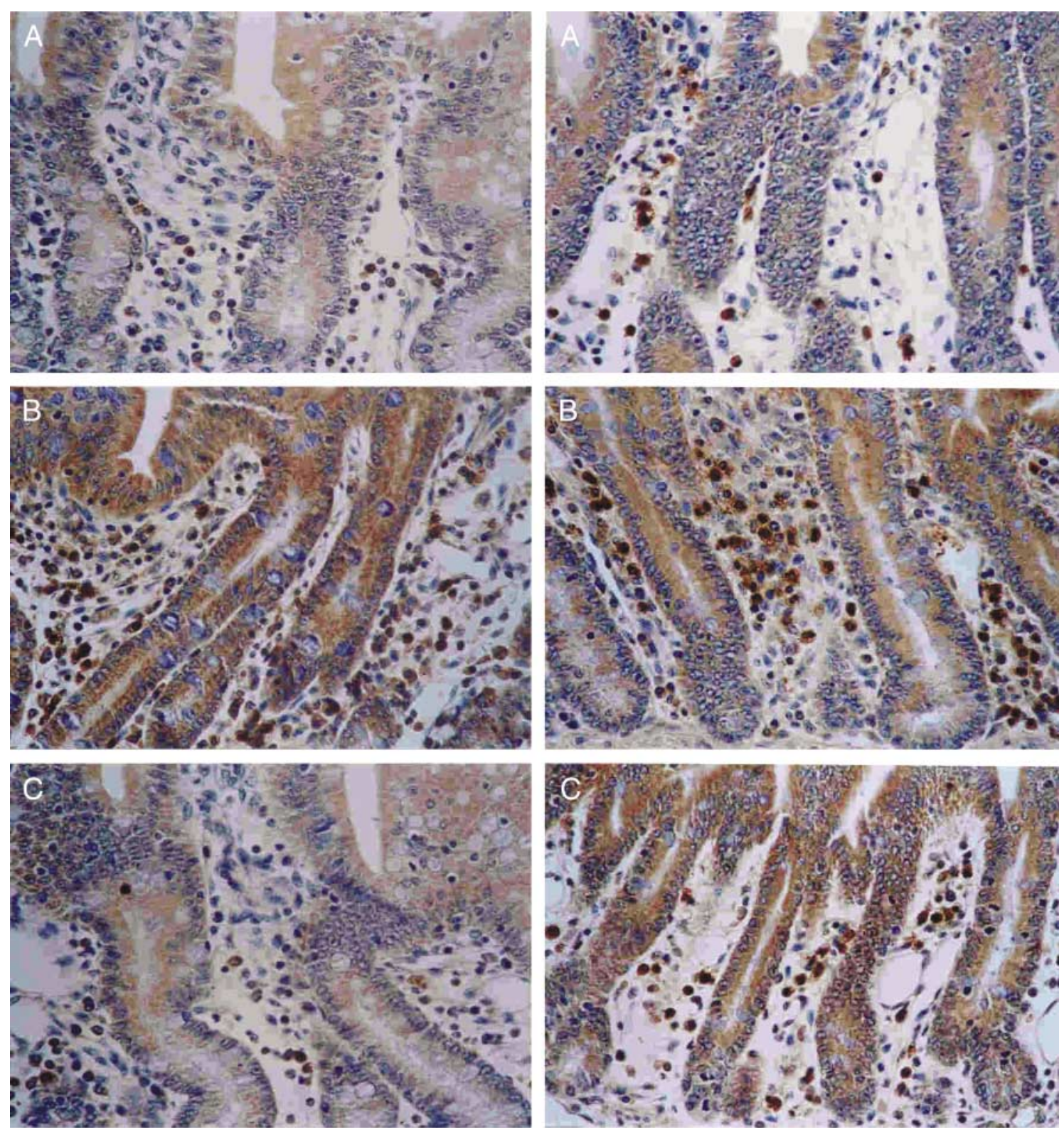

Fig. 2. Representative photomicrographs of duodenal (left panels) and ileal (right panels) crypts from pre-weaning (A), $4 \mathrm{~d}$ post-weaning (B) and $8 \mathrm{~d}$ post-weaning (C) pigs (magnification $350 \times$ ). Tissue sections were incubated with polyclonal antibodies against transforming growth factor- $\beta 1$ (TGF- $\beta 1$ ), and colour was developed using the avidin-peroxidase system. In the duodenum, the immunostaining at the crypt epithelium became much stronger in $4 \mathrm{~d}$ post-weaning pigs. In the ileum, there was an increase in staining for TGF- $\beta 1$ following weaning. The number of cells stained positively for TGF- $\beta 1$ in the lamina propria increased following weaning.

for TGF- $\beta 1$ at the crypts increased significantly $4 \mathrm{~d}$ after weaning. The integrated OD for TGF- $\beta 1$ at intestinal villi and crypts returned to the pre-weaning value by the eighth day after weaning (Fig. 4). In the ileal region of the small intestine, the OD for TGF- $\beta 1$ at villus epithelium decreased progressively until the eighth day after weaning. In contrast, the staining intensity for TGF- $\beta 1$ at the ileal crypts increased progressively after weaning (Fig. 4). The immunostaining intensities for TGF- $\beta 2$ and $\beta 3$ were relatively constant in most segments of the small intestine and did not change significantly following weaning (Fig. 4).

Western blot analysis revealed a positively stained band in all homogenized mucosal tissue samples and the band corresponded to the standard proteins of TGF- $\beta 1, \beta 2$ and $\beta 3$. The expression levels of TGF- $\beta 1, \beta 2$ and $\beta 3$ in homogenized small intestinal mucosa were also measured by Western blot analysis, and showed no significant changes in association with weaning (Fig. 5).

\section{Discussion}

Weaning is a physiologically important event that influences intestinal structure and function in the pig. Reports on the small intestine changes in morphology and brush-border hydrolase activities that occur in the weaning period are numerous. Studies in both laboratory animals (Pluske et al. 1997; van Beer-Schreurs et al. 1998) and human infants (Thompson et al. 1998) have shown that weaning is associated with villus atrophy, crypt hyperplasia and decrease in hydrolase-specific activities. The most severe reduction in villus height was observed in pigs $2-5 \mathrm{~d}$ post-weaning (Kelly et al. 
Table 1. The effects of weaning on intestinal morphology in the pig

(Mean values and standard error of the mean for four animals in each group)

\begin{tabular}{|c|c|c|c|c|c|c|}
\hline \multirow{2}{*}{ Region } & \multicolumn{2}{|c|}{ Pre-weaning pigs } & \multicolumn{2}{|c|}{$4 \mathrm{~d}$ post-weaning pigs } & \multicolumn{2}{|c|}{$8 \mathrm{~d}$ post-weaning pigs } \\
\hline & Mean & SEM & Mean & SEM & Mean & SEM \\
\hline \multicolumn{7}{|l|}{ Duodenum } \\
\hline Villus height $(\mu \mathrm{m})$ & $221 \cdot 1^{\mathrm{a}}$ & $9 \cdot 4$ & $122 \cdot 4^{\mathrm{b}}$ & $5 \cdot 1$ & $183 \cdot 6^{\mathrm{C}}$ & 8.8 \\
\hline Villus width $(\mu \mathrm{m})$ & $50 \cdot 8^{a}$ & 1.6 & $63 \cdot 2^{b}$ & $2 \cdot 1$ & $58 \cdot 4^{\mathrm{ab}}$ & 1.0 \\
\hline Crypt depth $(\mu \mathrm{m})$ & $85 \cdot 5^{a}$ & 3.4 & $113.4^{b}$ & 4.6 & $87 \cdot 6^{a}$ & $2 \cdot 7$ \\
\hline Villus:crypt ratio & $2 \cdot 6^{a}$ & 0.1 & $1 \cdot 1^{\mathrm{b}}$ & 0.0 & $2 \cdot 2^{a}$ & 0.2 \\
\hline \multicolumn{7}{|l|}{ Jejunum } \\
\hline Villus height $(\mu \mathrm{m})$ & $226 \cdot 6^{a}$ & 9.4 & $126 \cdot 9^{b}$ & 3.5 & $142 \cdot 7^{\mathrm{C}}$ & 1.9 \\
\hline Villus width $(\mu \mathrm{m})$ & $52 \cdot 9$ & $1 \cdot 3$ & $58 \cdot 3$ & $1 \cdot 0$ & $56 \cdot 9$ & $1 \cdot 2$ \\
\hline Crypt depth $(\mu \mathrm{m})$ & $78 \cdot 2^{\mathrm{ab}}$ & 4.5 & $83 \cdot 6^{\mathrm{a}}$ & 1.8 & $76 \cdot 4^{\mathrm{b}}$ & $2 \cdot 3$ \\
\hline Villus:crypt ratio & $3 \cdot 1^{\mathrm{a}}$ & 0.3 & $1 \cdot 5^{\mathrm{b}}$ & 0.0 & $1.9^{\mathrm{C}}$ & 0.1 \\
\hline \multicolumn{7}{|l|}{ Ileum } \\
\hline Villus height $(\mu \mathrm{m})$ & $155 \cdot 5^{\mathrm{a}}$ & 3.2 & $117 \cdot 6^{\mathrm{b}}$ & 3.5 & $120 \cdot 6^{\mathrm{b}}$ & $6 \cdot 3$ \\
\hline Villus width $(\mu \mathrm{m})$ & $55 \cdot 1^{\mathrm{a}}$ & 1.2 & $55 \cdot 1^{\mathrm{a}}$ & 0.9 & $65 \cdot 5^{\mathrm{b}}$ & 1.7 \\
\hline Crypt depth $(\mu \mathrm{m})$ & $66 \cdot 3^{a}$ & 1.5 & $79 \cdot 5^{\mathrm{b}}$ & 1.0 & $72 \cdot 8^{\mathrm{C}}$ & $2 \cdot 7$ \\
\hline Villus:crypt ratio & $2 \cdot 4^{\mathrm{a}}$ & 0.1 & $1 \cdot 5^{\mathrm{b}}$ & 0.1 & $1 \cdot 7^{\mathrm{b}}$ & 0.1 \\
\hline
\end{tabular}

a,b,c Mean values in the same row with unlike superscript letters were significantly different among animal groups: $P<0.05$.

1991; van Beers-Schreurs et al. 1998). In agreement with earlier reports, the present study showed that weaning caused significant villus shortening and crypt hyperplasia (Table 1) as well as significant declines in intestinal digestive enzyme activities (Table 2).

The causes of weaning-associated intestinal dysfunction have been a focal point of intensive research and have been related to reduced food intake, enteropathogens, hypersensitivity to dietary antigens and withdrawal of milk-borne growth factors (Pluske et al. 1996, 1997; McCracken et al. 1999). One of the milkborne growth factors, TGF- $\beta$, is of particular interest as it has known effects on enterocyte proliferation and differentiation and it modulates intestinal mucosal immune reactions (Massague, 1990). It has been speculated that TGF- $\beta$ may play an important role in post-weaning adaptation of the intestine (Xu et al. 2000). An earlier study in the rat showed that during the period of weaning the level of TGF- $\beta$ in maternal milk decreased markedly while the endogenous production of TGF- $\beta$ in the small intestine of the pup increased significantly (Penttila et al. 1998). In the present study, the expression levels of TGF- $\beta$ in the intestinal mucosa, when

Table 2. The specific activities ( $\mu \mathrm{mol} / \mathrm{g}$ protein per $\mathrm{min}$ ) of lactase, sucrase and alkaline phosphatase in intestinal mucosa of pre- and post-weaning pigs

(Mean values and standard error of the mean for four animals in each group)

\begin{tabular}{|c|c|c|c|c|c|c|}
\hline \multirow{2}{*}{ Enzyme } & \multicolumn{2}{|c|}{$\begin{array}{l}\text { Pre-weaning } \\
\text { pigs }\end{array}$} & \multicolumn{2}{|c|}{$\begin{array}{l}4 \mathrm{~d} \text { post-wean- } \\
\text { ing pigs }\end{array}$} & \multicolumn{2}{|c|}{$\begin{array}{l}8 \mathrm{~d} \text { post- } \\
\text { weaning pigs }\end{array}$} \\
\hline & Mean & SEM & Mean & SEM & Mean & SEM \\
\hline \multicolumn{7}{|l|}{ Lactase } \\
\hline Duodenum & $249 \cdot 8^{a}$ & $5 \cdot 8$ & $101 \cdot 9^{b}$ & $9 \cdot 2$ & $49 \cdot 8^{c}$ & $1 \cdot 2$ \\
\hline Jejunum & $267 \cdot 8^{a}$ & $10 \cdot 2$ & $100 \cdot 4^{\mathrm{b}}$ & 8.5 & $105 \cdot 9^{\mathrm{b}}$ & $16 \cdot 7$ \\
\hline Ileum & $208 \cdot 1^{a}$ & $26 \cdot 6$ & $34.6^{\mathrm{b}}$ & 3.6 & $9 \cdot 5^{\mathrm{c}}$ & 1.9 \\
\hline \multicolumn{7}{|l|}{ Sucrase } \\
\hline Duodenum & $48 \cdot 7^{a}$ & $3 \cdot 1$ & $14 \cdot 0^{b}$ & 1.5 & $9 \cdot 2^{b}$ & $1 \cdot 2$ \\
\hline Jejunum & $84.0^{a}$ & $2 \cdot 2$ & $35 \cdot 8^{\mathrm{b}}$ & 4.5 & $46 \cdot 9^{b}$ & 5.9 \\
\hline Ileum & $89.8^{a}$ & 7.9 & $35 \cdot 7^{\mathrm{b}}$ & 1.8 & $14 \cdot 8^{\mathrm{C}}$ & $1 \cdot 2$ \\
\hline \multicolumn{7}{|c|}{ Alkaline phosphatase } \\
\hline Duodenum & $3 \cdot 7^{\mathrm{a}}$ & 0.1 & $1 \cdot 3^{b}$ & 0.1 & $1.6^{\mathrm{b}}$ & 0.1 \\
\hline Jejunum & $3 \cdot 5^{a}$ & 0.3 & $1 \cdot 3^{b}$ & 0.1 & $1 \cdot 1^{\mathrm{b}}$ & 0.1 \\
\hline Ileum & $4 \cdot 6^{a}$ & 0.7 & $1 \cdot 7^{b}$ & 0.2 & $0.7^{b}$ & 0.1 \\
\hline
\end{tabular}

${ }^{a, b, c}$ Mean values in the same row with unlike superscript letters were significantly different among animal groups: $P<0.05$. estimated by Western blot analysis, did change significantly during weaning in pigs (Fig. 5). However, when examined by an immunostaining technique, the expression intensity for TGF- $\beta 1$ at the intestinal villus epithelium, particularly at the apical membrane of the epithelium, decreased significantly in pigs $4 \mathrm{~d}$ after weaning while the staining intensity at the intestinal crypts increased significantly in the same animals (Fig. 4). This finding indicates a topical change of TGF- $\beta$ expression in the small intestine of pigs during weaning and the change may relate to the withdrawal of milk-borne TGF- $\beta$ after weaning.

Our observation of topical changes in TGF- $\beta 1$ expression in the small intestine in association with weaning, with a transient increase in TGF- $\beta$ expression in the intestinal crypts and a decrease in the intestinal villi, is in contrast with the earlier report in rats that TGF- $\beta 1$ expression was most abundant in terminally differentiated villus tip cells and least abundant in the less differentiated crypt cells (Barnard et al. 1989). It has also been reported in the pig that the expression of inflammatory cytokines such as IL-1, IL- 6 and TNF- $\alpha$ increases in the intestine during weaning (McCracken et al. 1995; Pie et al. 2004). The apparent discrepancy between the present observations and the earlier



Fig. 3. The number of leucocytes staining positively for transforming growth factor- $\beta 1$ per villus-crypt unit in the intestinal lamina propria in pre-weaning (目), $4 \mathrm{~d}$ post-weaning ( $)$ and $8 \mathrm{~d}$ post-weaning (瓜) pigs. Values are means with the standard error of the mean shown by vertical bars for four animals in each group. ${ }^{a, b, c}$ Mean values with unlike superscript letters were significantly different among animal groups: $P<0.05$. 

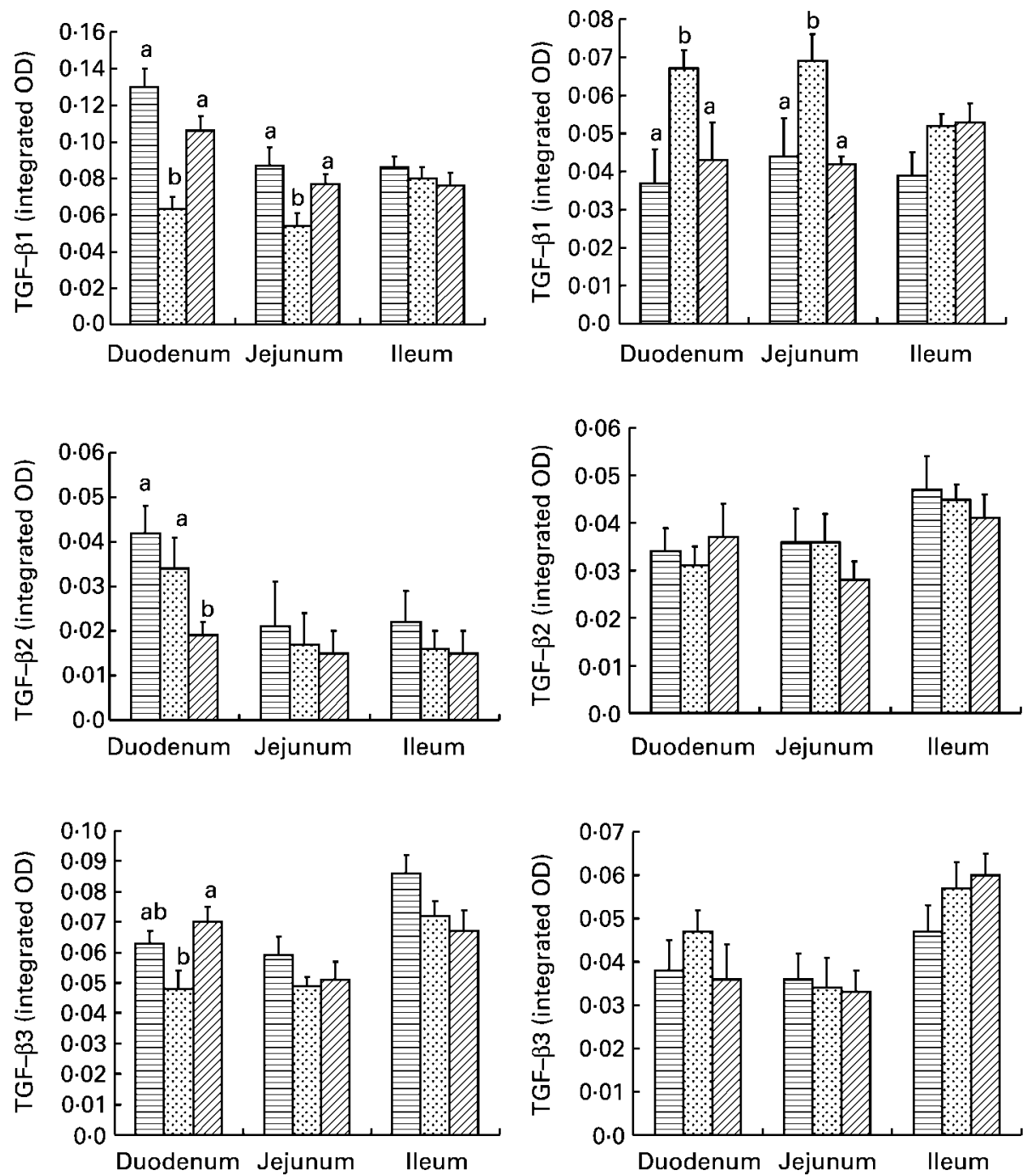

Fig. 4. The levels of transforming growth factor (TGF)- $\beta 1$, TGF- $\beta 2$ and TGF- $\beta 3$ in the villi (left panels) and crypts (right panels) of pre-weaning (目), $4 \mathrm{~d}$ post-weaning $(\square)$ and $8 \mathrm{~d}$ post-weaning (四) pigs estimated by immunostaining image analysis (for details see p. 38). Values are means, with the standard error of the mean shown by vertical bars for four animals in each group, of the integrated optical density (OD), which is the product of the area stained and the mean specific OD, and represents immunostaining intensity. ${ }^{\mathrm{a}, \mathrm{b}, \mathrm{c}}$ Mean values with unlike superscript letters were significantly different among animal groups: $P<0 \cdot 05$.

reports may be related to species and cytokine specificities. It is well known that the expression and the effect of different cytokines are tissue-specific. Further examination of the present results (Fig. 4) also showed that the expression level of TGF- $\beta 1$ was much greater in intestinal villi than in intestinal crypts in pre-weaning pigs, which is inconsistent with the earlier report in rats (Barnard et al. 1989).

The relationship between the decline in TGF- $\beta$ level of the intestinal villus epithelium and the reduction in intestinal villus height and mucosal digestive enzyme activities in post-weaning pigs is unclear. It has been reported in the literature that TGF- $\beta$ plays an important role in maintaining intestinal mucosa integrity and that it stimulates the mucosal wound healing process. TGF- $\beta$ stimulates the migration of epithelial cells from the wound margin and enhances rapid intestinal epithelial restitution (Ciacci et al. 1993). It has also been shown that TGF- $\beta$ enhances wound closure by stimulating collagen synthesis (Perr et al. 1996) and increasing the deposition of extracellular matrix (O'Kane \& Ferguson, 1997). Oral supplementation with a bovine milk fraction enriched for TGF- $\beta 2$ significantly reduced intestinal villus atrophy in rats exposed to the chemotherapy drug methotrexate (van't Land et al. 2002). From the earlier discussion, it may be speculated that the transient decline in TGF- $\beta 1$ level of the intestinal villus epithelium following weaning contributed to the post-weaning intestinal villus atrophy and to the reduction of digestive enzyme activities.

It was also observed in the present study that the number of TGF- $\beta 1$-positive leucocytes in pig intestinal lamina propria increased significantly $4 \mathrm{~d}$ after weaning (Fig. 3). The increment is likely due to an increased mucosal immune reaction to food antigens following weaning. It has been reported that the gut of earlyweaned pigs reacts to food antigens in a hypersensitive manner ( $\mathrm{Li}$ et al. 1990) and the local production of TGF- $\beta$ in gut-associated lymphoid tissue increases significantly in response to mucosal inflammation in patients with ulcerative colitis or Crohn's disease (Babyatsky et al. 1996; Hart et al. 2004). In mice TGF- $\beta$ production in gut-associated lymphoid tissue increased markedly following oral antigen challenge (Gonnella et al. 1998).

The transient increase of TGF- $\beta 1$-positive leucocytes in the intestinal mucosa in post-weaning pigs may play an important 

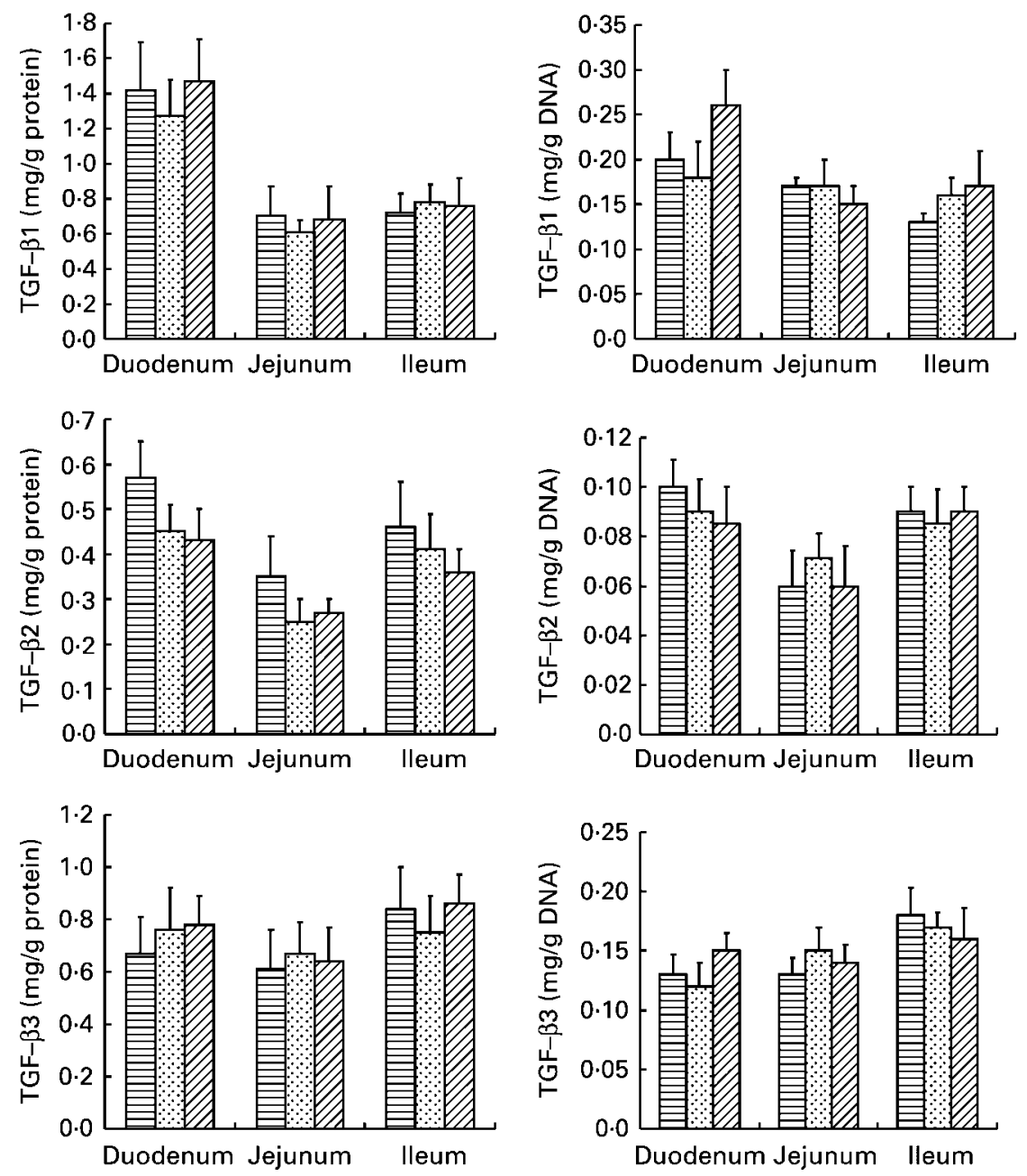

Fig. 5. The levels of transforming growth factor (TGF)- $\beta 1$, TGF- $\beta 2$ and TGF- $\beta 3$ in intestinal mucosa homogenates of pre-weaning (目), $4 \mathrm{~d}$ post-weaning ( $)$ and $8 \mathrm{~d}$ post-weaning (Wigs estimated by Western blot analysis. Values are means, with the standard error of the mean shown by vertical bars for four animals in each group, of mg TGF- $\beta / \mathrm{g}$ protein (left panels) and mg TGF- $\beta / \mathrm{mg}$ DNA (right panels). There were no significant differences in TGF- $\beta$ levels among animal groups.

role in the process of post-weaning intestinal adaptation. TGF- $\beta$ is an important cytokine controlling mucosal inflammation and immune response. It has been shown that TGF- $\beta$ inhibits leucocyte proliferation and activation (Letterio \& Roberts, 1998). Abrogation of TGF- $\beta$ signalling in T cells induces T-cell-mediated inflammatory lesions in various organs including the intestine (Gorelik \& Flavell, 2000). In vitro studies have shown that TGF- $\beta$ inhibits macrophages and glioma cells from expressing MHC class II antigens (Czarniecki et al. 1988). TGF- $\beta 1$ and TGF- $\beta 2$ decrease secretion of pro-inflammatory cytokines (IL-6, IL-8) induced by both TNF- $\alpha$ and IL-1 $\beta$ in a human intestinal epithelial cell line (Claud et al. 2003; Walia et al. 2003). Mice with TGF- $\beta 1$ deficiency die from cardiac, pulmonary and gastric inflammation, suggesting that TGF- $\beta$ has a vital role in suppressing the activation and proliferation of inflammatory cells (Shull et al. 1992). TGF- $\beta$ also plays an important role in oral tolerance. Oral administration of recombinant TGF- $\beta$ or milk whey extract containing a high concentration of TGF- $\beta$ to neonatal mice strongly inhibits the immune response to an oral antigen challenge (Penttila et al. 2001).

The present study did not find significant changes in TGF- $\beta 2$ and $\beta 3$ expression in the small intestine of the pig during the weaning period. The significance of the different expression patterns of the three TGF- $\beta$ isoforms is unknown. Although highly homologous in structure and similar in biological activities in many bioassay systems, the TGF- $\beta$ isoforms are encoded by different genes and have different distributions and biological actions within the body (Blobe et al. 2000). TGF- $\beta 1$ is the most abundant isoform in all tissues and in human platelets. More than $85 \%$ of the TGF- $\beta$ in the wound fluid in adult animals is TGF- $\beta 1$. TGF- $\beta 2$ is the most abundant isoform in body fluids, including the aqueous and vitreous fluid of the eye, saliva, amniotic fluid and breast milk, while TGF- $\beta 3$ is usually the least abundant isoform in both tissues and body fluids (Massague, 1990). The different physiological functions of TGF- $\beta$ isoforms have been demonstrated in gene knockout mice. TGF- $\beta 1$ null mice can survive in the perinatal period when nursed by their dams but die of excessive inflammatory reactions after weaning (Shull et al. 1992). In contrast, TGF- $\beta 2$ null mice display a wide range of developmental heart, lung, craniofacial, limb, spinal column, eye, inner ear and urogenital defects (Sanford et al. 1997), while TGF- $\beta 3$ null mice die during the early postnatal period owing to defects in pulmonary development and palatogenesis (Proetzel et al. 1995). Neither TGF- $\beta 2$ nor TGF- $\beta 3$ can overcome the deficit of TGF- $\beta 1$ (McCartney-Francis \& Wahl, 1994). It has 
been shown that TGF- $\beta 1$ and TGF- $\beta 3$ are significantly more effective in inducing migration of epithelial cells across the wound edge and enhancing epithelial restitution in wounded IEC-6 monolayers than TGF- $\beta 2$ (McKaig et al. 2002). The different expression patterns of the three TGF- $\beta$ isoforms during the weaning period may reflect a tissue-specific and spatio-temporal mechanism of TGF- $\beta$ in regulating intestinal structure and function.

It was observed in the present study that the level of TGF- $\beta$ in the intestinal mucosal homogenate estimated by Western blot analysis did not change significantly in the pig during the period of weaning (Fig. 5), which is in contrast with the results from image analysis of the immunostaining (Fig. 4). The possible explanation for this discrepancy is the different approaches with the two analytical methods. Western blot analysis estimated the TGF- $\beta$ level in the homogenated mucosal tissue while image analysis of the immunostaining estimated the TGF- $\beta$ level in different tissue locations in the small intestinal mucosa. The decrease in TGF- $\beta$ level in the villus epithelium in association with weaning was accompanied by increased TGF- $\beta$ concentration in the crypt region as observed by the immunostaining, thus the net effect of these two opposing responses would be no change in the TGF- $\beta$ concentration in the homogenized mucosal tissue.

In summary, the present study demonstrated that TGF- $\beta$ distribution and expression intensity in the small intestine change markedly in pigs in association with weaning. There was a transient decline in TGF- $\beta 1$ level in the intestinal villus epithelium but a significant increase in TGF- $\beta 1$ expression in the intestinal crypts in pigs following weaning. In addition, the number of TGF- $\beta$ 1-positive leucocytes in the intestinal mucosa increased significantly in pigs $4 \mathrm{~d}$ after weaning. These findings, together with the earlier reports of TGF- $\beta$ effects on intestinal epithelial integrity and mucosal immune reaction, strongly suggest a regulatory role of TGF- $\beta$ in the post-weaning adaptation process of the intestine. This knowledge may facilitate our understanding of the aetiology of post-weaning intestinal dysfunction in the pig.

\section{Acknowledgements}

This work was supported by a grant from Hong Kong Research Grants Council (HKU 7366/03M). The authors wish to thank $\mathrm{Mr}$ Victor Yeung and Mr Yuesang Cheung for their technical support. We also wish to acknowledge the contribution of Dr Dale King and Miss Siu Yin Man to the present study.

\section{References}

Babyatsky MW, Rossiter G \& Podolsky DK (1996) Expression of transforming growth factors alpha and beta in colonic mucosa in inflammatory bowel disease. Gastroenterology 110, 975-984.

Barnard JA, Beauchamp RD, Coffey RJ \& Moses HL (1989) Regulation of intestinal epithelial cell growth by transforming growth factor type beta. Proc Natl Acad Sci USA 86, 1578-1582.

Barnard JA, Warwick GJ \& Gold LI (1993) Localization of transforming growth factor beta isoforms in the normal murine small intestine and colon. Gastroenterology 105, 67-73.

Blobe GC, Schiemann WP \& Lodish HF (2000) Role of transforming growth factor beta in human disease. N Engl J Med 342, 1350-1358.

Ciacci C, Lind SE \& Podolsky DK (1993) Transforming growth factor beta regulation of migration in wounded rat intestinal epithelial monolayers. Gastroenterology 105, 93-101.

Claud EC, Savidge T \& Walker WA (2003) Modulation of human intestinal epithelial cell IL-8 secretion by human milk factors. Pediatr Res 53, 419-425.

Czarniecki CW, Chiu HH, Wong GH, McCabe SM \& Palladino MA (1988) Transforming growth factor-beta 1 modulates the expression of class II histocompatibility antigens on human cells. J Immunol 140, 4217-4223.

Dahlqvist A (1964) Method for assay of intestinal disaccharides. Anal Biochem 7, 18-25.

Dignass AU \& Sturm A (2001) Peptide growth factors in the intestine. Eur J Gastroenterol Hepatol 13, 763-770.

Forstner GG, Sabesin SM \& Isselbacher KJ (1968) Rat intestinal microvillus membranes. Purification and biochemical characterization. Biochem J 106, 381-390.

Giles KW \& Myers A (1964) The role of nucleic acids in the growth of the hypocotyls of lupinus albus under varying light and dark regimes. Biochim Biophys Acta 87, 460-477.

Gonnella PA, Chen Y, Inobe J, Komagata Y, Quartulli M \& Weiner HL (1998) In situ immune response in gut-associated lymphoid tissue (GALT) following oral antigen in TCR-transgenic mice. J Immunol 160, 4708-4718.

Gorelik L \& Flavell RA (2000) Abrogation of TGFbeta signaling in T cells leads to spontaneous $\mathrm{T}$ cell differentiation and autoimmune disease. Immunity 12, 171-181.

Hampson DJ \& Kidder DE (1986) Influence of creep feeding and weaning on brush border enzyme activities in the piglet small intestine. Res Vet Sci 40, 24-31.

Hart AL, Kamm MA, Knight SC \& Stagg AJ (2004) Quantitative and functional characteristics of intestinal-homing memory T cells: analysis of Crohn's disease patients and healthy controls. Clin Exp Immunol 135, 137-145.

Johnson LR \& Chandler AM (1973) RNA and DNA of gastric and duodenal mucosa in antrectomized and gastrin-treated rats. Am J Physiol 224, 937-940.

Kelly D, Smyth JA \& McCracken KJ (1991) Digestive development of the early-weaned pig. 2. Effect of level of food intake on digestive enzyme activity during the immediate post-weaning period. $\mathrm{Br} J$ Nutr $\mathbf{6 5}$, $181-188$.

Letterio JJ \& Roberts AB (1998) Regulation of immune responses by TGF- $\beta$. Annu Rev Immunol 16, 137-161.

Li DF, Nelssen JL, Reddy PG, Blecha F, Hancock JD, Allee GL, Goodband RD \& Klemm RD (1990) Transient hypersensitivity to soybean meal in the early-weaned pig. J Anim Sci 68, 1790-1799.

Lowry OH, Rosebrough NJ, Farr AL \& Randall RJ (1951) Protein measurement with the folin phenol reagent. J Biol Chem 193, 265-275.

Massague J (1990) The transforming growth factor-beta family. Annu Rev Cell Biol 6, 597-641.

McCartney-Francis NL \& Wahl SM (1994) Transforming growth factor beta: a matter of life and death. J Leukoc Biol 55, 401-409.

McCracken BA, Gaskins HR, Ruwe-Kaiser PJ, Klasing KC \& Jewell DE (1995) Diet-dependent and diet-independent metabolic responses underlie growth stasis of pigs at weaning. J Nutr 125, 2838-2845.

McCracken BA, Spurlock ME, Roos MA, Zuckermann FA \& Gaskins HR (1999) Weaning anorexia may contribute to local inflammation in the piglet small intestine. J Nutr 129, 613-619.

McKaig BC, Hughes K, Tighe PJ \& Mahida YR (2002) Differential expression of TGF-beta isoforms by normal and inflammatory bowel disease intestinal myofibroblasts. Am J Physiol Cell Physiol 282, C172-C182.

Mei J, Zhang YQ, King D, Sangild P \& Xu RJ (2004) Distribution and developmental changes of transforming growth factor-beta receptors in the small intestine of the pig. J Anim Vet Adv 3, 89-106.

O'Kane S \& Ferguson MW (1997) Transforming growth factor betas and wound healing. Int J Biochem Cell Biol 29, 63-78.

Penttila IA, van Spriel AB, Zhang MF, Xian CJ, Steeb CB, Cummins AG, Zola H \& Read LC (1998) Transforming growth factor-beta levels in maternal milk and expression in postnatal rat duodenum and ileum. Pediatr Res 44, 524-531. 
Penttila IA, Zhang MF, Bates E, Regester G, Read LC \& Zola H (2001) Immune modulation in suckling rat pups by a growth factor extract derived from milk whey. J Dairy Res 68, 587-599.

Perr H, Oh P \& Johnson D (1996) Developmental regulation of transforming growth factor beta-mediated collagen synthesis in human intestinal muscle cells. Gastroenterology 110, 92-101.

Pie S, Lalles JP, Blazy F, Laffitte J, Seve B \& Oswald IP (2004) Weaning is associated with an upregulation of expression of inflammatory cytokines in the intestine of piglets. J Nutr 134, 641-647.

Pluske JR, Williams IH \& Aherne FX (1996) Maintenance of villous height and crypt depth in piglets by providing continuous nutrition after weaning. Anim Sci 62, 131-144.

Pluske JR, Hampson DJ \& Williams IH (1997) Factors influencing the structure and function of the small intestine in the weaned pig: a review. Livestock Prod Sci 51, 215-236.

Proetzel G, Pawlowski SA, Wiles MV, Yin M, Boivin GP, Howles PN, Ding J, Ferguson MW \& Doetschman T (1995) Transforming growth factor-beta 3 is required for secondary palate fusion. Nat Genet 11, 409-414.

Rao JN, Li L, Bass BL \& Wang JY (2000) Expression of the TGF-beta receptor gene and sensitivity to growth inhibition following polyamine depletion. Am J Physiol Cell Physiol 279, C1034-C1044.

Roberts AB (1995) Transforming growth factor-beta: activity and efficacy in animal models of wound healing. Wound Rep Reg 3, 408-418.

Ruifrok AC, Mason KA, Lozano G \& Thames HD (1997) Spatial and temporal patterns of expression of epidermal growth factor, transforming growth factor alpha and transforming growth factor beta 1-3 and their receptors in mouse jejunum after radiation treatment. Radiat Res 147, 1-12.

Sanford LP, Ormsby I, Gittenberger-de Groot AC, Sariola H, Friedman R, Boivin GP, Cardell EL \& Doetschman T (1997) TGFbeta2 knockout mice have multiple developmental defects that are non-overlapping with other TGFbeta knockout phenotypes. Development 124, 2659-2670.

Shull MM, Ormsby I, Kier AB, et al. (1992) Targeted disruption of the mouse transforming growth factor-beta 1 gene results in multifocal inflammatory disease. Nature 359, 693-699.

Thompson FM, Catto-Smith AG, Moore D, Davidson G \& Cummins AG (1998) Epithelial growth of the small intestine in human infants. $J$ Pediatr Gastroenterol Nutr 26, 506-512.

van Beers-Schreurs HM, Nabuurs MJ, Vellenga L, Kalsbeek-van der Valk HJ, Wensing T \& Breukink HJ (1998) Weaning and the weanling diet influence the villus height and crypt depth in the small intestine of pigs and alter the concentrations of short-chain fatty acids in the large intestine and blood. $J$ Nutr 128, 947-953.

van't Land B, Meijer HP, Frerichs J, Koetsier M, Jager D, Smeets RL, M'Rabet L \& Hoijer M (2002) Transforming growth factor-beta2 protects the small intestine during methotrexate treatment in rats possibly by reducing stem cell cycling. Br J Cancer 87, 113-118.

Walia B, Wang L, Merlin D \& Sitaraman SV (2003) TGF-beta downregulates IL-6 signaling in intestinal epithelial cells: critical role of SMAD-2. FASEB $J$ 17, 2130-2132.

$\mathrm{Xu}$ RJ, Mellor DJ, Tungthanathanich P, Birtles MJ, Reynolds GW \& Simpson HV (1992) Growth and morphological changes in the small and the large intestine in piglets during the first three days after birth. J Dev Physiol 18, 161-172.

Xu RJ, Wang F \& Zhang SH (2000) Postnatal adaptation of the gastrointestinal tract in neonatal pigs: a possible role of milk-borne growth factors. Livestock Prod Sci 66, 95-107.

Yue J \& Mulder KM (2001) Transforming growth factor-beta signal transduction in epithelial cells. Pharmacol Ther 91, 1-34. 